\title{
Prevalence of FRAX risk factors and the osteoporosis treatment gap among women $\geq 70$ years of age in routine primary care across 8 countries in Europe
}

\author{
Eugene McCloskey ${ }^{1}$. Jeetandera Rathi ${ }^{2}$. Stephane Heijmans ${ }^{3} \cdot$ Mark Blagden $^{4} \cdot$ Bernard Cortet $^{5}$. \\ Edward Czerwinski $^{6} \cdot$ Peyman Hadji ${ }^{7,8}$. Juraj Payer ${ }^{9} \cdot$ Kerry Palmer $^{10} \cdot$ Robert Stad $^{11}$. James O'Kelly ${ }^{10}$. \\ Socrates Papapoulos ${ }^{12}$
}

Received: 23 July 2021 / Accepted: 6 December 2021 / Published online: 22 January 2022

(c) The Author(s) 2022

\begin{abstract}
Summary We studied whether elderly women at risk for fractures receive primary care treatment to prevent fracture. We found that across Europe, women at risk are often not identified, and less than half of such women receive appropriate treatment. Finally, women diagnosed with osteoporosis are much more likely to receive treatment.

Purpose To examine the relationship between risk factors for fragility fracture (FF) and osteoporosis (OP) treatment gap in elderly women across Europe, and compare the prevalence of risk factors between countries.

Methods Demographic and clinical information was collected from women $\geq 70$ years visiting primary care physicians in Belgium, France, Germany, Ireland, Poland, Slovakia, Switzerland, and the UK. Increased risk of FF was defined by the presence of 1 or more criteria (history of fracture, 10-year fracture probability, or $T$-score $\leq-2.5$ ).

Results There were 3798 women in total. Treatment gap (proportion at increased risk of FF not receiving treatment for OP) varied from 53.1 to $90.8 \%$ across countries, and the proportion of patients at increased risk of FF varied from 41.2 to $76.1 \%$. Across countries, less than $50 \%$ of patients with increased risk of FF had a diagnosis of OP. Previous fracture was the most common risk factor, with similar prevalence across most countries; other risk factors varied widely. The treatment gap was reduced in patients with an OP diagnosis in all countries, but this reduction varied from 36.5 to $79.4 \%$. The countries with the lowest rates of bone densitometry scans (Poland, France, and Germany; 8.3-12.3\%) also had the highest treatment gap $(82.2$ to $90.8 \%)$.

Conclusions This study highlights differences across Europe in clinical risk factors for fracture, rates of densitometry scanning, and the rates of OP diagnosis. More emphasis is needed on risk assessment to improve the identification and treatment of elderly women at risk for fracture.
\end{abstract}

Keywords Fragility fracture · Fracture Risk Assessment Tool (FRAX) · Risk factors · Observational study · Osteoporosis · Treatment gap

\section{Introduction}

Osteoporosis (OP) is a systemic disease characterized by low bone mass and deterioration of bone tissue, which results in bone fragility and an increased risk of fracture [1]. Bone loss accelerates in the year just before menopause and remains high as long as $4-8$ years after menopause, with women

Eugene McCloskey

E.V.McCloskey@sheffield.ac.uk

Extended author information available on the last page of the article losing on average $10 \%$ of their bone mineral density (BMD) during the menopausal transition [2]. In 2015, the prevalence of BMD-defined OP in women aged 50 or more across the EU5 (France, Germany, Italy, Spain, and UK) and Sweden ranged from $21.8 \%$ in the UK to $23.1 \%$ in Italy [3]. The related fractures were found to impose a substantial economic burden in these countries, with direct costs in 2017 ranging from $€ 1199$ million in Sweden to $€ 8176$ million in Germany [3].

Dual-energy X-ray absorptiometry (DXA) is the most widely used technique for measuring BMD, upon which the diagnosis of OP is generally based. Tools such as the FRAX 
fracture risk assessment tool developed at the University of Sheffield, which integrates clinical risk factors and BMD, are being commonly used to calculate the risk of fracture [4]. Increasingly, FRAX values are used to set national or international thresholds for assessment and/or treatment to identify patients to be targeted for pharmacotherapy [5-8]. Despite this, only a minority of women eligible for treatment receive appropriate treatment [9]. In 2010, the estimated treatment gap in Europe varied from $26 \%$ in Ireland to $78 \%$ in Poland $[10,11]$. More recent studies have indicated that the treatment gap persists; e.g., $>75 \%$ of respondents (representative of the general French population) 50 years or older who reported a fracture had not been diagnosed with OP, or received appropriate care [12], and the treatment gap in women in the EU5 and Sweden was estimated as $73 \%$ for 2017 [3]. The primary analysis from our recent study of 8 European countries confirmed this large treatment gap $(74.6 \%)$ in women aged $\geq 70$ years at increased risk of FF in routine primary care across Europe [13]. The gap appeared to be related to a low rate of OP diagnosis. In this analysis, we wished to examine the relationship between fracture risk factors and the treatment gap across the 8 countries. In addition, the study provided an opportunity to compare the prevalence of fracture risk factors over the same countries.

\section{Methods}

Detailed methods for this cross-sectional, multicenter, observational study have been published previously [13].

\section{Study design, data collection method, study population, and recruitment}

Following informed consent, community-dwelling women 70 years or older across 8 countries (Belgium, France, Germany, Ireland, Poland, Slovakia, Switzerland, and the UK) filled a short questionnaire when spontaneously visiting their GP between 28 March 2018 and 26 October 2018. Demographics, baseline characteristics, and other information (reason for consultation, any known OP diagnosis, risk factors for fracture, comorbidities, and OP medications used in the last 10 years) were collected using the questionnaires and patient medical records.

\section{Primary and key secondary objectives}

This publication reports further analysis from the study (the primary analysis of which has been published; see [13]). The objective of this analysis was to compare the prevalence of clinical risk factors for fracture in the 8 countries in the study, and examine any relationship between fracture risk factors and the treatment gap across these countries.

\section{Definition of increased risk of FF}

A patient was considered at increased risk of FF if at least 1 of the following 3 criteria was met: (a) history of fracture after the age of 50 (hip, spine, wrist, or other OP-related fractures); (b) increased 10-year probability of both hip and major osteoporotic fracture (calculated using the FRAX tool without BMD) above the country-specific threshold, which was calculated using an approach similar to that of the National Osteoporosis Guidance Group, UK ([13, 14]; see Online Resource Table S1); (c) BMD $T$-score $\leq-2.5$ for lumbar spine, total hip, or femoral neck.

\section{Statistical methods}

No formal hypothesis was tested. A sample size of 4000 (500/country) was expected to estimate the primary outcome for each participating country with sufficient precision. All analyses were descriptive. Baseline patient characteristics, OP medication use, and clinical risk factors were summarized by country. The primary outcome (OP treatment gap) was summarized by country for important clinical risk factors and for OP diagnosis (yes or no).

\section{Results}

A total of 3798 patients were enrolled; approximately 500 per country (except for Switzerland, $n=205$ ), across 153 sites.

\section{Baseline characteristics}

The median age of patients ranged from 76.0 in Ireland, Poland, and Slovakia to 79.0 in France; median body mass index (BMI) ranged from $25.5 \mathrm{~kg} / \mathrm{m}^{2}$ in Switzerland to $28.7 \mathrm{~kg} / \mathrm{m}^{2}$ in Slovakia. The most common reason for consultation was "follow-up to known disease" in 7 of 8 countries (ranging from $36.4 \%$ in Poland to $73.8 \%$ in Slovakia); in France, "medication refill" (48.8\%) was the most common reason (Table 1).

Across countries, most patients did not have an OP diagnosis (Table 1); the proportion with an OP diagnosis ranged from $15.0 \%$ in Poland to $30.2 \%$ in Switzerland. Belgium, Switzerland, and Ireland had a relatively high proportion of patients with DXA assessments (37.2 to 44.6\%); other countries ranged from $8.3 \%$ (Poland) to $27.4 \%$ (UK). For interpretation of BMD and $T$-score data, it should be noted that DXA assessments were available only for a subgroup of 944 patients (24.9\% of the study cohort). 
Table 1 Baseline characteristics, OP diagnosis, comorbidities, clinical risk factors, and 10-year risk of FF by country

\begin{tabular}{|c|c|c|c|c|c|c|c|c|c|}
\hline & $\begin{array}{l}\text { Belgium } \\
(N=505)\end{array}$ & $\begin{array}{l}\text { France } \\
(N=543)\end{array}$ & $\begin{array}{l}\text { Germany } \\
(N=506)\end{array}$ & $\begin{array}{l}\text { Ireland } \\
(N=\mathbf{5 0 0})\end{array}$ & $\begin{array}{l}\text { Poland } \\
(N=505)\end{array}$ & $\begin{array}{l}\text { Slovakia } \\
(N=534)\end{array}$ & $\begin{array}{l}\text { Switzerland } \\
(N=205)\end{array}$ & $\begin{array}{l}\text { UK } \\
(N=500)\end{array}$ & $\begin{array}{l}\text { Overall } \\
N=3798\end{array}$ \\
\hline $\begin{array}{l}\text { Age, median } \\
\text { (Q1, Q3), } \\
\text { years }\end{array}$ & $\begin{array}{l}78.0(74.0, \\
82.0)\end{array}$ & $\begin{array}{c}79.0(74.0, \\
84.0)\end{array}$ & $\begin{array}{l}78.0(74.0, \\
81.0)\end{array}$ & $\begin{array}{l}76.0(73.0 \\
81.0)\end{array}$ & $\begin{array}{l}76.0(72.0 \\
80.0)\end{array}$ & $\begin{array}{l}76.0(72.0 \\
80.0)\end{array}$ & $\begin{array}{l}78.0(74.0, \\
83.0)\end{array}$ & $\begin{array}{c}77.0(73.0, \\
82.0)\end{array}$ & $\begin{array}{l}77.0(73.0, \\
82.0)\end{array}$ \\
\hline $\begin{array}{l}\text { BMI, median } \\
\text { (Q1, Q3), } \\
\mathrm{kg} / \mathrm{m}^{2}\end{array}$ & $\begin{array}{c}27.1(23.8, \\
30.2)\end{array}$ & $\begin{array}{l}25.6(22.8, \\
29.7)\end{array}$ & $\begin{array}{l}26.5(23.2 \\
29.7)\end{array}$ & $\begin{array}{l}27.1(23.9 \\
30.5)\end{array}$ & $\begin{array}{l}27.5(25.2 \\
31.2)^{*}\end{array}$ & $\begin{array}{l}28.7(25.7, \\
32.1)\end{array}$ & $\begin{array}{l}25.5(22.8, \\
29.1)\end{array}$ & $\begin{array}{c}26.6(23.8, \\
30.7)\end{array}$ & $\begin{array}{c}26.9(23.9, \\
30.5)^{* *}\end{array}$ \\
\hline \multicolumn{10}{|c|}{ Reason for consultation, $n(\%)$} \\
\hline $\begin{array}{l}\text { Follow-up } \\
\text { to known } \\
\text { disease }\end{array}$ & $226(44.8)$ & $168(30.9)$ & $368(72.7)$ & $209(41.8)$ & $184(36.4)$ & $394(73.8)$ & $141(68.8)$ & $288(57.6)$ & $1978(52.1)$ \\
\hline $\begin{array}{l}\text { Medica- } \\
\text { tion refill }\end{array}$ & $151(29.9)$ & $265(48.8)$ & $57(11.3)$ & $39(7.8)$ & $165(32.7)$ & $68(12.7)$ & $21(10.2)$ & $16(3.2)$ & $782(20.6)$ \\
\hline $\begin{array}{l}\text { New } \\
\text { symp- } \\
\text { toms/ } \\
\text { com- } \\
\text { plaints }\end{array}$ & $110(21.8)$ & $72(13.3)$ & $72(14.2)$ & $170(34.0)$ & $134(26.5)$ & $55(10.3)$ & $41(20.0)$ & $170(34.0)$ & $824(21.7)$ \\
\hline Other & $18(3.6)$ & $38(7.0)$ & $9(1.8)$ & $82(16.4)$ & $22(4.4)$ & $17(3.2)$ & $2(1.0)$ & $26(5.2)$ & $214(5.6)$ \\
\hline $\begin{array}{l}\text { Known OP } \\
\text { diagnosis, } \\
\text { n }(\%)\end{array}$ & $125(24.8)$ & $107(19.7)$ & $82(16.2)$ & $129(25.8)$ & $76(15.0)$ & $144(27.0)$ & $62(30.2)$ & $79(15.8)$ & $804(21.2)$ \\
\hline $\begin{array}{l}\text { DXA assess- } \\
\text { ment }\end{array}$ & $188(37.2)$ & $62(11.4)$ & $62(12.3)$ & $223(44.6)$ & $42(8.3)$ & $139(26.0)$ & $91(44.4)$ & $137(27.4)$ & $944(24.9)$ \\
\hline $\begin{array}{l}\text { Increased } \\
\text { risk of } \\
\mathrm{FF}-n(\%)\end{array}$ & $286(56.6)$ & $376(69.3)$ & $295(58.3)$ & $241(48.2)$ & $259(51.3)$ & $220(41.2)$ & $156(76.1)$ & $244(48.8)$ & $2077(54.7)$ \\
\hline $\begin{array}{l}\text { With a } \\
\text { diagnosis } \\
\text { of OP }\end{array}$ & $107(37.4)$ & $88(23.4)$ & $60(20.3)$ & $101(41.9)$ & $62(23.9)$ & $95(43.2)$ & $62(39.7)$ & $66(27.0)$ & $641(30.9)$ \\
\hline $\begin{array}{l}\text { At least one } \\
\text { comorbid- } \\
\text { ity, } n(\%)\end{array}$ & 438 (86.7) & 471 (86.7) & 438 (86.6) & $416(83.2)$ & 479 (94.9) & $504(94.4)$ & $183(89.3)$ & $432(86.4)$ & $3361(88.5)$ \\
\hline RA & $18(3.6)$ & $27(5.0)$ & $25(4.9)$ & $16(3.2)$ & $16(3.2)$ & $21(3.9)$ & $7(3.4)$ & $21(4.2)$ & $151(4.0)$ \\
\hline Diabetes & 104 (20.6) & $91(16.8)$ & $187(37.0)$ & $69(13.8)$ & $148(29.3)$ & $214(40.1)$ & $44(21.5)$ & $96(19.2)$ & $953(25.1)$ \\
\hline $\begin{array}{l}\text { Hyperten- } \\
\text { sion }\end{array}$ & 372 (73.7) & $368(67.8)$ & $401(79.2)$ & $331(66.2)$ & $435(86.1)$ & 487 (91.2) & $137(66.8)$ & 309 (61.8) & $2840(74.8)$ \\
\hline $\begin{array}{l}\text { Osteoar- } \\
\text { thritis }\end{array}$ & $242(47.9)$ & $348(64.1)$ & $117(23.1)$ & $237(47.4)$ & $235(46.5)$ & $129(24.2)$ & $129(62.9)$ & $265(53.0)$ & $1702(44.8)$ \\
\hline COPD & 40 (7.9) & $39(7.2)$ & $53(10.5)$ & 58 (11.6) & $32(6.3)$ & $35(6.6)$ & $13(6.3)$ & 57 (11.4) & 327 (8.6) \\
\hline \multicolumn{10}{|c|}{ Clinical risk factors for $\mathrm{FF}-n(\%)$} \\
\hline $\begin{array}{l}\text { Previous } \\
\text { fracture }\end{array}$ & $159(31.5)$ & $148(27.3)$ & $151(29.8)$ & $155(31.0)$ & $156(30.9)$ & $178(33.3)$ & $96(46.8)$ & $157(31.4)$ & $1200(31.6)$ \\
\hline Hip & $22(4.4)$ & $20(3.7)$ & $17(3.4)$ & $21(4.2)$ & $16(3.2)$ & $19(3.6)$ & $8(3.9)$ & $22(4.4)$ & $145(3.8)$ \\
\hline Spine & $26(5.1)$ & $21(3.9)$ & $28(5.5)$ & $14(2.8)$ & $22(4.4)$ & $24(4.5)$ & $31(15.1)$ & $12(2.4)$ & $178(4.7)$ \\
\hline Wrist & $62(12.3)$ & $54(9.9)$ & $53(10.5)$ & $52(10.4)$ & $69(13.7)$ & $73(13.7)$ & $22(10.7)$ & $50(10.0)$ & $435(11.5)$ \\
\hline $\begin{array}{l}\text { Other } \\
\text { (except } \\
\text { skull, } \\
\text { finger } \\
\text { and toe } \\
\text { fractures) }\end{array}$ & $77(15.2)$ & $70(12.9)$ & $97(19.2)$ & $86(17.2)$ & $74(14.7)$ & $89(16.7)$ & $51(24.9)$ & $90(18.0)$ & $634(16.7)$ \\
\hline $\begin{array}{l}\text { Parental hip } \\
\text { fracture }\end{array}$ & $53(10.5)$ & $75(13.8)$ & $42(8.3)$ & $35(7.0)$ & $41(8.1)$ & $44(8.2)$ & $27(13.2)$ & $49(9.8)$ & $366(9.6)$ \\
\hline $\begin{array}{l}\text { Current } \\
\text { smoker }\end{array}$ & $34(6.7)$ & $27(5.0)$ & $35(6.9)$ & $33(6.6)$ & $28(5.5)$ & $25(4.7)$ & $14(6.8)$ & $35(7.0)$ & $231(6.1)$ \\
\hline
\end{tabular}


Table 1 (continued)

\begin{tabular}{|c|c|c|c|c|c|c|c|c|c|}
\hline & $\begin{array}{l}\text { Belgium } \\
(N=505)\end{array}$ & $\begin{array}{l}\text { France } \\
(N=543)\end{array}$ & $\begin{array}{l}\text { Germany } \\
(N=506)\end{array}$ & $\begin{array}{l}\text { Ireland } \\
(N=500)\end{array}$ & $\begin{array}{l}\text { Poland } \\
(N=505)\end{array}$ & $\begin{array}{l}\text { Slovakia } \\
(N=534)\end{array}$ & $\begin{array}{l}\text { Switzerland } \\
(N=205)\end{array}$ & $\begin{array}{l}\text { UK } \\
(N=500)\end{array}$ & $\begin{array}{l}\text { Overall } \\
N=3798\end{array}$ \\
\hline $\begin{array}{l}\text { Glucocorti- } \\
\text { coid use }\end{array}$ & $18(3.6)$ & $17(3.1)$ & $23(4.5)$ & $33(6.6)$ & $21(4.2)$ & $9(1.7)$ & $14(6.8)$ & $41(8.2)$ & $176(4.6)$ \\
\hline $\begin{array}{l}\text { Alcohol }(\geq 3 \\
\text { units per } \\
\text { day) }\end{array}$ & $6(1.2)$ & $3(0.6)$ & $4(0.8)$ & $9(1.8)$ & $0(0.0)$ & $2(0.4)$ & $7(3.4)$ & $19(3.8)$ & $50(1.3)$ \\
\hline $\begin{array}{l}\text { Femoral } \\
\text { neck } \\
\text { T-score } \\
\text { - median } \\
\text { (Q1, Q3) } \\
\text { [n] }\end{array}$ & $\begin{array}{l}-1.9(-2.4 \\
-1.1)[124]\end{array}$ & $\begin{array}{l}-1.4(-2.0 \\
-0.4)[35]\end{array}$ & $\begin{array}{l}-1.3(-2.3 \\
-0.8)[48]\end{array}$ & $\begin{array}{l}-1.5(-2.1, \\
-0.7)[203]\end{array}$ & $\begin{array}{l}-2.0(-2.7 \\
-1.4)[21]\end{array}$ & $\begin{array}{l}-1.4(-2.0 \\
-0.9)[124]\end{array}$ & $\begin{array}{l}-2.0(-2.6 \\
-1.2)[86]\end{array}$ & $\begin{array}{l}-1.3(-2.1 \\
-0.4)[86]\end{array}$ & $\begin{array}{c}-1.6(-2.3, \\
-0.8) \\
{[727]}\end{array}$ \\
\hline \multicolumn{10}{|c|}{ 10-year fracture probability without BMD - median (Q1, Q3), \% } \\
\hline Hip fracture & $\begin{array}{c}8.8(4.8 \\
13.9)\end{array}$ & $\begin{array}{c}8.8(4.7 \\
13.8)\end{array}$ & $\begin{array}{c}7.6(4.9, \\
11.7)\end{array}$ & $\begin{array}{c}7.7(5.1 \\
12.3)\end{array}$ & $\begin{array}{c}3.7(2.3 \\
6.5)^{*}\end{array}$ & $6.1(3.9,9.3)$ & $\begin{array}{l}12.2(7.4 \\
20.1)\end{array}$ & $\begin{array}{c}7.2(4.1 \\
12.1)\end{array}$ & $\begin{array}{l}7.2(4.1 \\
11.9)^{* *}\end{array}$ \\
\hline $\begin{array}{c}\text { Major OP } \\
\text { fracture }\end{array}$ & $\begin{array}{c}18.3(13.1, \\
24.3)\end{array}$ & $\begin{array}{l}18.3(11.2, \\
25.5)\end{array}$ & $\begin{array}{l}16.6(12.1, \\
22.7)\end{array}$ & $\begin{array}{l}18.0(13.8, \\
25.0)\end{array}$ & $\begin{array}{c}9.5(6.7 \\
13.8)^{*}\end{array}$ & $\begin{array}{l}14.5(10.9, \\
20.1)\end{array}$ & $\begin{array}{l}29.3(23.7 \\
39.3)\end{array}$ & $\begin{array}{l}18.3(13.0, \\
24.6)\end{array}$ & $\begin{array}{c}16.6(11.5, \\
23.9)^{* *}\end{array}$ \\
\hline
\end{tabular}

$B M D$, bone mineral density; $B M I$, body mass index; $C O P D$, chronic obstructive pulmonary disease; $D X A$, dual-energy X-ray absorptiometry; $F F$, fragility fracture; $O P$, osteoporosis; $R A$, rheumatoid arthritis

$N$, number of patients enrolled in full analysis set. Percentages based on number of patients enrolled in full analysis set

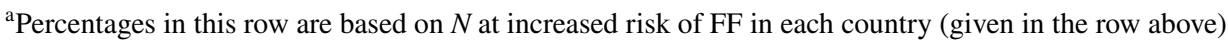

${ }^{*} N=485 .{ }^{* *} N=3778$

Note: Patients may be counted in more than one comorbidity

France and Switzerland had the highest proportion of patients at increased risk of FF $(69.3 \%$ and $76.1 \%)$, and Slovakia had the lowest (41.2\%). Across countries, $<50 \%$ of the patients with increased risk of FF had a diagnosis of OP, ranging from $20.3 \%$ in Germany to $43.2 \%$ in Slovakia (Table 1).

Baseline characteristics and reasons for consultations for patients at increased risk of FF were similar to the total populations in all countries (Online Resource Table S2).

\section{Comorbidities}

Most patients in all countries reported at least one comorbidity, ranging from $83.2 \%$ in Ireland to $94.9 \%$ in Poland (Table 1). Of the 5 comorbidities on which data were collected, hypertension was the most prevalent (ranging from $61.8 \%$ in the UK to $91.2 \%$ in Slovakia), and rheumatoid arthritis (RA) the least prevalent (ranging from 3.2\% in Ireland and Poland to $5.0 \%$ in France). The countries with the highest proportion of patients at increased risk of FF also had the highest prevalence of osteoarthritis (France $64.1 \%$ and Switzerland $62.9 \%$ ), and the country with the lowest proportion of patients at increased risk of FF had the lowest prevalence of osteoarthritis (Slovakia 24.2\%). However, in general, there was no obvious pattern between the prevalence of comorbidities and the fracture risk between countries.

\section{Clinical risk factors for FF}

In the study population as a whole, previous fracture was the most commonly reported clinical risk factor (Table 1), with similar prevalence across most countries (from $27.3 \%$ in France to $33.3 \%$ in Slovakia); except for Switzerland, which had a relatively high prevalence (46.8\%) as a result of more frequent spine (15.1\%) and "other" (24.9\%) fractures. Variation was seen across countries for the risk factors of parental hip fracture (7.0\% in Ireland to $13.8 \%$ in France), current smoking (4.7\% in Slovakia to $7.0 \%$ in the UK), glucocorticoid use (1.7\% in Slovakia to $8.2 \%$ in the UK), and alcohol intake of 3 or more units daily $(0.0 \%$ in Poland to $3.8 \%$ in the UK). Median femoral neck $T$-score ranged from -1.3 in Germany and the UK to -2.0 in Poland and Switzerland.

Previous fracture was also the most common risk factor in patients with increased risk of FF (Online Resource Table S2). As expected, prevalence was higher than for the total patient group, ranging from $39.4 \%$ in France to $80.9 \%$ in Slovakia. Variation across countries was seen in clinical risk factors including parental hip fracture $(12.0 \%$ in Ireland to $17.3 \%$ in France and Switzerland), current smoking (4.5\% in Slovakia to $8.3 \%$ in Switzerland), glucocorticoid 
use $(3.2 \%$ in Slovakia to $12.9 \%$ in Ireland), RA (3.8\% in Switzerland to $8.1 \%$ in Germany), alcohol intake of 3 or more units daily ( $0.0 \%$ in Poland to $4.1 \%$ in the UK), and median femoral neck $T$-score (-1.3 in Germany to -2.5 in Poland).

\section{0-year probability of hip and major OP fracture}

Ten-year probability of hip and major OP fracture in patients without BMD assessment was similar across most countries (Table 1); hip: $6.1 \%$ in Slovakia to $8.8 \%$ in Belgium and France; major OP: $14.5 \%$ in Slovakia to $18.3 \%$ in Belgium, France, and the UK. Values were notably lower for Poland (hip: 3.7\%; major OP: 9.5\%) and higher for Switzerland (hip: 12.2\%; major OP: $29.3 \%$ ). A similar pattern was seen for patients at increased risk of FF (Online Resource Table S2); as expected, values were higher than for all patients (hip: $6.4 \%$ in Poland to $14.5 \%$ in Switzerland; major OP: $13.7 \%$ in Poland to $32.8 \%$ in Switzerland).

\section{OP treatment gap}

The primary outcome (OP treatment gap in patients at increased risk of FF) varied across countries (Fig. 1 and Table 2). Germany had the highest treatment gap $(90.8 \%$ [95\% CI: 87.0-93.9\%], while Ireland had the lowest (53.1\%
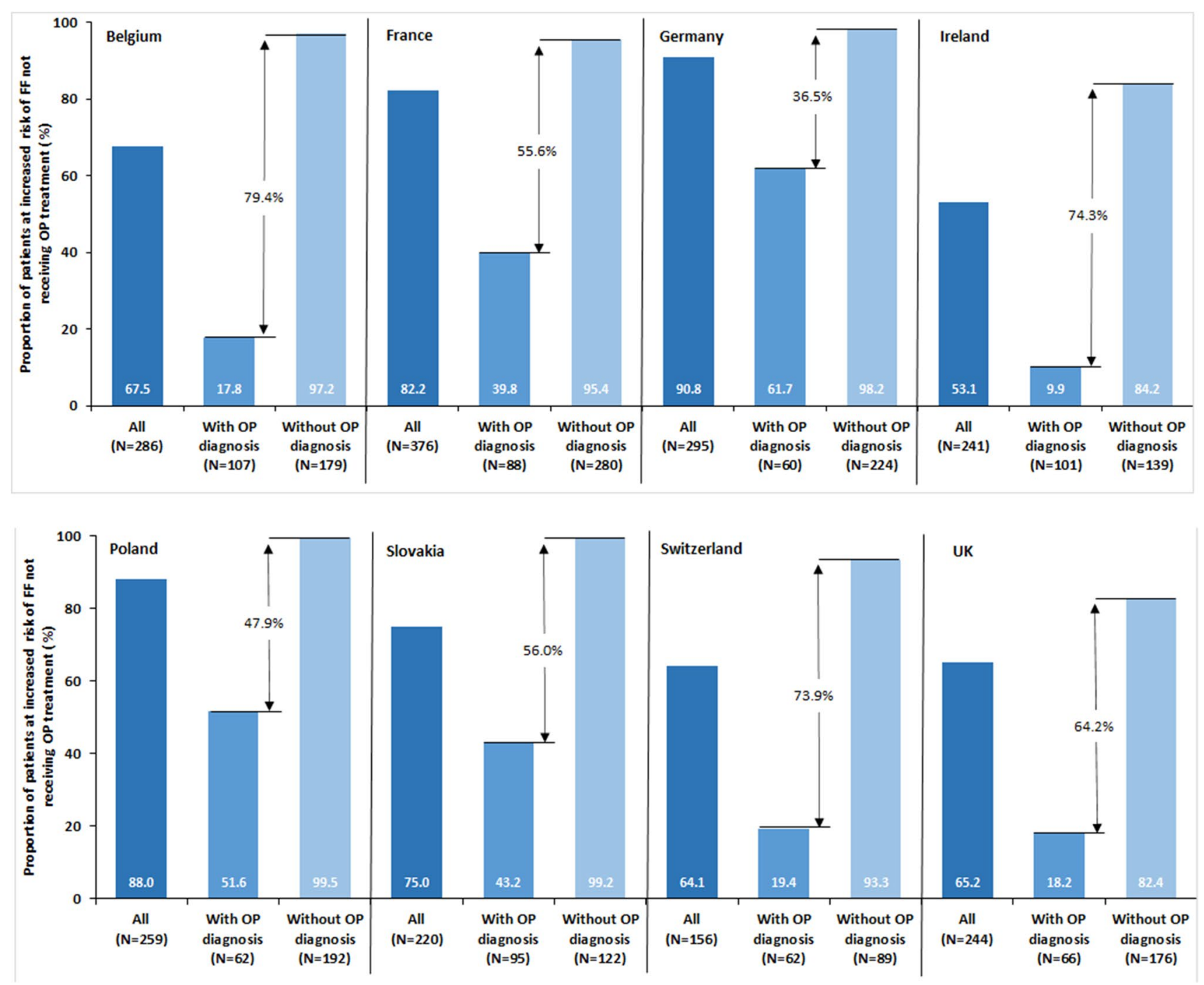

Fig. 1 Osteoporosis treatment gap in elderly women in 8 European countries by osteoporosis diagnosis. For each country, the bars show the proportion (\%) of patients at increased risk of fragility fracture who were not receiving treatment for osteoporosis (i.e., the treatment gap). Numbers within columns represent the treatment gap. Number $(N)$ at increased risk of fragility fracture is shown beneath each column. "All": Treatment gap overall; "With OP Diagnosis": Treatment gap in patients who had an osteoporosis diagnosis; "Without OP Diagnosis": Treatment gap in patients who did not have an osteoporosis diagnosis. The percentage shown within arrows is the difference in treatment gap between those with an OP diagnosis and those without. $F F$, fragility fracture; $O P$, osteoporosis 
Table 2 Primary outcome (treatment gap) for patients with history of fracture, $T$-score $\leq-2.5$, or who exceeded country-specific FRAX threshold

\begin{tabular}{|c|c|c|c|c|c|c|c|c|c|}
\hline $\begin{array}{l}\text { Increased } \\
\text { risk of } \\
\text { fragility } \\
\text { fracture }\end{array}$ & Belgium & France & Germany & Ireland & Poland & Slovakia & Switzerland & UK & Total \\
\hline \multicolumn{10}{|c|}{ All patients } \\
\hline$N$ & 286 & 376 & 295 & 241 & 259 & 220 & 156 & 244 & 2077 \\
\hline$n(\%)$ & $193(67.5)$ & 309 (82.2) & $268(90.8)$ & $128(53.1)$ & $228(88.0)$ & $165(75.0)$ & $100(64.1)$ & $159(65.2)$ & $1550(74.6)$ \\
\hline$(95 \% \mathrm{CI})$ & $(61.7,72.9)$ & $(77.9,85.9)$ & $(87.0,93.9)$ & $(46.6,59.6)$ & $(83.4,91.7)$ & $(68.7,80.6)$ & $(56.0,71.6)$ & $(58.8,71.1)$ & $(72.7,76.5)$ \\
\hline \multicolumn{10}{|c|}{ Any fracture } \\
\hline$N$ & 159 & 148 & 151 & 155 & 156 & 178 & 96 & 157 & 1200 \\
\hline$n(\%)$ & $102(64.2)$ & $112(75.7)$ & $129(85.4)$ & $87(56.1)$ & 134 (85.9) & 138 (77.5) & $55(57.3)$ & $100(63.7)$ & 857 (71.4) \\
\hline$(95 \% \mathrm{CI})$ & $\begin{array}{c}(56.17, \\
71.59)\end{array}$ & $\begin{array}{c}(67.95, \\
82.35)\end{array}$ & $\begin{array}{c}\text { (78.78, } \\
90.64)\end{array}$ & $\begin{array}{c}(47.94 \\
64.08)\end{array}$ & $\begin{array}{c}(79.43 \\
90.95)\end{array}$ & $\begin{array}{c}\text { (70.68, } \\
83.43)\end{array}$ & $\begin{array}{c}(46.78, \\
67.34)\end{array}$ & $\begin{array}{c}(55.65, \\
71.21)\end{array}$ & $\begin{array}{c}(68.77 \\
73.96)\end{array}$ \\
\hline \multicolumn{10}{|c|}{ Hip fracture } \\
\hline$N$ & 22 & 20 & 17 & 21 & 16 & 19 & 8 & 22 & 145 \\
\hline$n(\%)$ & $10(45.5)$ & $12(60.0)$ & $16(94.1)$ & $9(42.9)$ & $12(75.0)$ & $15(78.9)$ & 7 (87.5) & $12(54.5)$ & $93(64.1)$ \\
\hline$(95 \% \mathrm{CI})$ & $\begin{array}{c}(24.39 \\
67.79)\end{array}$ & $\begin{array}{c}(36.05 \\
80.88)\end{array}$ & $\begin{array}{c}\text { (71.31, } \\
99.85)\end{array}$ & $\begin{array}{c}(21.82, \\
65.98)\end{array}$ & $\begin{array}{c}\text { (47.62) } \\
92.73)\end{array}$ & $\begin{array}{c}(54.43, \\
93.95)\end{array}$ & $\begin{array}{c}(47.35, \\
99.68)\end{array}$ & $\begin{array}{c}(32.21, \\
75.61)\end{array}$ & $\begin{array}{c}(55.76 \\
71.93)\end{array}$ \\
\hline \multicolumn{10}{|c|}{ Spine fracture } \\
\hline$N$ & 26 & 21 & 28 & 14 & 22 & 24 & 31 & 12 & 178 \\
\hline$n(\%)$ & $4(15.4)$ & $13(61.9)$ & $18(64.3)$ & $4(28.6)$ & $12(54.5)$ & $13(54.2)$ & $9(29.0)$ & $2(16.7)$ & $75(42.1)$ \\
\hline$(95 \% \mathrm{CI})$ & $(4.36,34.87)$ & $\begin{array}{c}(38.44, \\
81.89)\end{array}$ & $\begin{array}{c}(44.07, \\
81.36)\end{array}$ & $(8.39,58.10)$ & $\begin{array}{c}(32.21 \\
75.61)\end{array}$ & $\begin{array}{c}(32.82, \\
74.45)\end{array}$ & $\begin{array}{c}(14.22, \\
48.04)\end{array}$ & $(2.09,48.41)$ & $\begin{array}{c}(34.79 \\
49.75)\end{array}$ \\
\hline \multicolumn{10}{|c|}{$T$-score $\leq-2.5$} \\
\hline$N$ & 64 & 19 & 17 & 62 & 20 & 44 & 54 & 38 & 318 \\
\hline$n(\%)$ & $10(15.6)$ & $4(21.1)$ & $9(52.9)$ & $5(8.1)$ & $4(20.0)$ & $15(34.1)$ & $13(24.1)$ & $6(15.8)$ & $66(20.8)$ \\
\hline$(95 \% \mathrm{CI})$ & $(7.76,26.86)$ & $(6.05,45.57)$ & $\begin{array}{c}(27.81 \\
77.02)\end{array}$ & $(2.67,17.83)$ & $(5.73,43.66)$ & $\begin{array}{c}(20.49 \\
49.92)\end{array}$ & $\begin{array}{c}(13.49 \\
37.64)\end{array}$ & $(6.02,31.25)$ & $\begin{array}{c}(16.43 \\
25.63)\end{array}$ \\
\hline \multicolumn{10}{|c|}{ Exceeded FRAX threshold } \\
\hline$N$ & 255 & 370 & 275 & 195 & 219 & 149 & 140 & 211 & 1814 \\
\hline$n(\%)$ & $178(69.8)$ & $305(82.4)$ & $252(91.6)$ & $108(55.4)$ & $197(90.0)$ & $114(76.5)$ & $86(61.4)$ & 137 (64.9) & $1377(75.9)$ \\
\hline$(95 \% \mathrm{CI})$ & $\begin{array}{c}(63.77, \\
75.38)\end{array}$ & $\begin{array}{c}(78.16, \\
86.17)\end{array}$ & $\begin{array}{c}\text { (87.71, } \\
94.62)\end{array}$ & $\begin{array}{c}(48.11 \\
62.49)\end{array}$ & $\begin{array}{c}(85.19, \\
93.60)\end{array}$ & $\begin{array}{c}(68.88, \\
83.06)\end{array}$ & $\begin{array}{c}(52.84 \\
69.53)\end{array}$ & $\begin{array}{c}(58.08, \\
71.35)\end{array}$ & $\begin{array}{c}(73.87, \\
77.86)\end{array}$ \\
\hline
\end{tabular}

$B M D$, bone mineral density; $C I$, confidence interval; $D X A$, dual-energy X-ray absorptiometry; $F F$, fragility fracture; $F R A X$, Fracture Risk Assessment Tool; $O P$, osteoporosis

$N$, number of patients who are at increased risk of FF-using definition 1 (without BMD). n, number of patients not receiving any OP medication. Percentages based on number of patients enrolled who are at increased risk of FF

${ }^{a}$ A patient will be considered to be at increased risk of $\mathrm{FF}$ if $\geq 1$ of the 3 following criteria are met: (1) had a history of fracture; (2) 10-year probability of hip fracture without BMD > country-specific threshold and 10-year probability of major osteoporotic fracture without BMD > countryspecific threshold; (3) BMD $T$-score $\leq-2.5$ for any of lumbar spine/total hip/femoral neck

[46.6-59.5\%]). The treatment gap was notably reduced in patients who had an OP diagnosis (Fig. 1; arrows display difference in treatment gap between those with an OP diagnosis and those without). The difference ranged from $36.5 \%$ in Germany to $79.4 \%$ in Belgium.

Across countries, the treatment gap was lower in those with spine fracture than for all patients at increased risk of FF (Table 2), with the lowest treatment gap in this group observed in Belgium and the UK (15-17\%). The effect of hip fracture was less pronounced: the treatment gap was lower in those with hip fracture than all patients in Belgium, France, Ireland, Poland, and the UK; but higher in Germany, Slovakia, and Switzerland.

In all countries, the treatment gap was substantially lower in those with $T$-scores $\leq-2.5$ than all patients at increased risk of FF (Table 2). Across countries, the treatment gap in patients who exceeded the country-specific FRAX threshold was similar to the treatment gap for all patients at increased risk of FF. 
Table 3 OP medication use

\begin{tabular}{|c|c|c|c|c|c|c|c|c|c|}
\hline $\begin{array}{l}\text { Any OP } \\
\text { medication, } \\
n(\%)\end{array}$ & $\begin{array}{l}\text { Belgium } \\
(N=110)\end{array}$ & $\begin{array}{l}\text { France } \\
(N=75)\end{array}$ & $\begin{array}{l}\text { Germany } \\
(N=32)\end{array}$ & $\begin{array}{l}\text { Ireland } \\
(N=143)\end{array}$ & $\begin{array}{l}\text { Poland } \\
(N=39)\end{array}$ & $\begin{array}{l}\text { Slovakia } \\
(N=69)\end{array}$ & $\begin{array}{l}\text { Switzerland } \\
(N=56)\end{array}$ & $\begin{array}{l}\mathrm{UK} \\
(N=102)\end{array}$ & $\begin{array}{l}\text { Total } \\
(N=626)\end{array}$ \\
\hline Denosumab & $46(41.8)$ & $12(16.0)$ & $15(46.9)$ & 57 (39.9) & 7 (17.9) & $18(26.1)$ & $31(55.4)$ & $1(1.0)$ & $187(29.9)$ \\
\hline Oral BP & $65(59.1)$ & $44(58.7)$ & $19(59.4)$ & $106(74.1)$ & $34(87.2)$ & $38(55.1)$ & $18(32.1)$ & $98(96.1)$ & $422(67.4)$ \\
\hline $\begin{array}{l}\text { Parenteral } \\
\text { BP }\end{array}$ & $24(21.8)$ & $7(9.3)$ & 5 (15.6) & $3(2.1)$ & $3(7.7)$ & $18(26.1)$ & $19(33.9)$ & $6(5.9)$ & 85 (13.6) \\
\hline PTH & $2(1.8)$ & $0(0.0)$ & $0(0.0)$ & $4(2.8)$ & $0(0.0)$ & $0(0.0)$ & $2(3.6)$ & $0(0.0)$ & $8(1.3)$ \\
\hline SERM & 14 (12.7) & 14 (18.7) & $1(3.1)$ & $4(2.8)$ & $0(0.0)$ & $5(7.2)$ & $1(1.8)$ & $2(2.0)$ & $41(6.5)$ \\
\hline Strontium & $2(1.8)$ & $12(16.0)$ & $2(6.3)$ & $12(8.4)$ & $0(0.0)$ & $6(8.7)$ & $0(0.0)$ & $6(5.9)$ & $40(6.4)$ \\
\hline
\end{tabular}

$B P s$, bisphosphonates; $O P$, osteoporosis; PTH, parathyroid hormone; RANKL, receptor activator of nuclear factor kappa-B ligand; SERMs, selective estrogen receptor modulators

$N$, number of patients enrolled who are receiving or have received any OP medication in the last 10 years

Note: Percentages add up to more than $100 \%$ because patients may be counted under more than one medication; and both concurrent and previous medications are included. OP medication use is derived considering SERMs, oral BPs, parenteral BPs, strontium, PTH, and anti-RANKL/ denosumab medications

\section{OP medication use}

For all countries except Switzerland, oral BPs were the most commonly used type of OP medication (ranging from 32.1\% [of those using any OP medication] in Switzerland to 96.1\% in the UK; Table 3). Belgium, Germany, Ireland, and Switzerland had relatively high proportions of patients using denosumab (39.9 to 55.4\% of those using any OP medication) while France, Poland, and the UK had comparatively low proportions (1.0 to $17.9 \%$ ).

\section{Discussion}

Our study found a large treatment gap for women aged $\geq 70$ years at increased risk of FF who were in routine primary care across 8 countries in Europe. While the treatment gap varied (53.1\% in Ireland to $90.8 \%$ in Germany), it was above $50 \%$ in all 8 countries. Across countries, the treatment gap was lower in patients with an OP diagnosis, with the difference between patients with and without a diagnosis ranging from $36.5 \%$ in Germany to $79.4 \%$ in Belgium.

Studies in other regions of the world have also identified a large OP treatment gap among older or postmenopausal women (in these studies, the treatment gap was usually defined as the proportion who did not receive OP medication in a defined period after a primary fracture or an OP diagnosis). In the USA, the treatment gap was reported as $72.1 \%$ (data from the Women's Health Initiative study [15]) and $81.4 \%$ [16]; in Asia, treatment gap varied from 64.5\% in a multi-country study in China and South-East Asia [17] to as high as $98.6 \%$ in a cross-sectional study in China [18].

The demographic characteristics of the European women over $\geq 70$ recruited in this study were comparable across the
8 countries. The proportion of patients with an OP diagnosis varied from $15.0 \%$ (Poland) to $30.2 \%$ (Switzerland). Across countries, less than a third of the patients had had a DXA scan, except in Belgium, Switzerland, and Ireland (37.2 to $44.6 \%)$. The proportion of patients at increased risk of FF varied from $41.2 \%$ (Slovakia) to $76.1 \%$ (Switzerland). Of this subset of patients, $<50 \%$ had a diagnosis of OP (from $20.3 \%$ in Germany to $43.2 \%$ in Slovakia). Previous fracture was the most commonly reported clinical risk factor for FF, with similar prevalence across all countries (27.3 to $33.3 \%$ ) except Switzerland (46.8\%). Other risk factors, such as parental hip fracture, rheumatoid arthritis, glucocorticoid use, smoking, alcohol intake, and median $T$-score, varied widely. Ten-year probability of hip and major OP fracture was similar in all countries (6.1 to $8.8 \%$ for hip fracture and 14.5 to $18.3 \%$ for major OP fracture), except for Poland (3.7\% for hip fracture and 9.5\% of major OP fracture) and Switzerland (12.2\% for hip fracture and $29.3 \%$ for major OP). Overall, the rank order of the prevalence of risk factors was similar in all countries though absolute prevalence showed some variation. Despite this variability, the absolute FRAX probabilities were fairly similar, with the possible exception of Poland and Switzerland, showing the predominant impact of prior fracture.

An earlier study [10], which used a different methodology and was not limited to primary care, reported lower treatment gaps for the countries in our study; however, that study also identified Ireland as having the lowest treatment gap (26\%). The treatment gap in our study was substantially lower in patients diagnosed with OP; however, the gap in these patients also varied across countries, from $9.9 \%$ in Ireland to $61.7 \%$ in Germany. This suggests there are substantial differences across Europe in how well women eligible for OP treatment are identified, as well as differences 
in treatment uptake in those who are diagnosed with OP. In some countries, such as Germany, most OP patients may be treated by orthopedic physicians instead of general practitioners (GPs), which could contribute to a low rate of DXA measurements and a high treatment gap. The involvement of GPs is an important aspect of OP prevention and management. Two studies in France revealed that physician's attitudes and lack of awareness of OP can be a significant barrier to identifying and treating patients at risk for fracture $[19,20]$. Physicians' attitudes also influence those of the OP patients themselves, which can have an impact on treatment adherence [19]. A qualitative study in Sweden [21] found that primary care physicians perceive OP as a silent disease that is overshadowed by other conditions and seen as a low priority. The recently published SCOPE scorecard provides a detailed comparison of OP epidemiology and care across Europe, including estimate of the treatment gap in those aged 50 or more [22]. The treatment gap in Europe was estimated to be $71 \%$ overall, and as for our study was lowest in Ireland (32\%). Gaps in knowledge, diverse opinions on who should be responsible for management, and uncertainty about treatment protocol could affect the management of OP. Furthermore, FRAX use may be limited by absence of linkage to electronic medical records.

The FRAX uptake reported in SCOPE was substantially lower in those countries where we found a higher treatment gap in our study (Germany, France, Poland, and Slovakia) [22]. In our study, the three countries with the lowest rates of DXA scans (Poland [8.3\%], France [11.4\%], and Germany $[12.3 \%]$ ) also had the highest treatment gap overall $(88.0 \%, 82.2 \%$, and $90.8 \%$, respectively); conversely, Ireland, with the highest rate of scans (44.6\%), had the lowest treatment gap (53.1\%). Availability of DXA is similar across all countries except Poland and the UK, and scans are fully or partially reimbursed in all the countries [22]; therefore, differences observed in rates of DXA between countries may reflect differences in awareness of OP and fracture risk, which in turn drives the treatment gap.

The impact of clinical risk factors on the treatment gap varied between countries. The countries with highest treatment gap overall (Poland and Germany) also had high treatment gaps in patients who exceeded the country-specific FRAX threshold $(90.0 \%$ and $91.6 \%)$, and in patients with hip fractures (75.0\% and 94.1\%); conversely, Ireland (with the lowest treatment gap overall) had the lowest treatment gap in patients who exceeded the FRAX threshold as well as in patients with hip fracture (55.4\% and $42.9 \%$ ). Ireland also had the lowest treatment gap in patients with $T$-scores less than $-2.5(8.1 \%)$. These data suggest that although physicians consider known clinical risk factors when making treatment decisions, there is variability in the weighting given to individual risk factors when identifying patients for treatment in some countries.
Among OP medications, oral BPs were used at high rates in most countries in our study (32.1 to $96.1 \%$ of those using any OP medication), reflecting their use as a standard firstline treatment. Denosumab was used at relatively high rates in Belgium, Germany, Ireland, and Switzerland (39.9 to $55.4 \%$ ), and at low rates in other countries (1.0 to $26.1 \%$ ), which may be due to differences in access or reimbursement. In general, the other medications assessed (parenteral BP, PTH, SERM, and strontium) were used at low rates. Treatment patterns reported in the literature are consistent with these findings. BPs were reported as by far the dominant treatment in UK primary care for the period 2010 to 2015 [23]. An analysis of German pharmacy prescription data showed that most first-time prescriptions between 2010 and 2014 were for oral BPs, but denosumab treatment was more common than found in the UK study [24].

This study has some important strengths as well as limitations. GPs willing and able to participate in observational studies could represent a specialized subgroup; therefore, as noted earlier [13], steps were taken to reduce bias during recruitment. The prevalence of risk factors and comorbidities agreed with that reported earlier [25-30], indicating that the study population is typical for this demographic. However, since the patients were women $\geq 70$ years visiting their GP, they may not be representative of the general population. The study was not also designed to establish causality between the prevalence of risk factors and treatment gap. All analyses were descriptive; no statistical comparisons were made across countries. The sample sizes were small in relation to the total number of women with OP in the countries in the study, and therefore the results may not be representative. This is especially true for Switzerland, which had the smallest number of subjects (205, across 6 sites).

In conclusion, our study highlights differences across countries in Europe with respect to clinical risk factors for fracture, DXA scanning, and the rates of OP diagnosis. The OP treatment gap differed but still fewer than $50 \%$ of women at increased risk of FF were treated in any country. Our findings suggest that there is variable success across Europe in identifying and treating women at risk for fracture. More emphasis needs to be placed on BMD measurements as a tool for screening elderly women, and on the use of FRAX or other risk assessment tools. It is also important that patients and physicians across Europe be educated about the importance of screening and prevention measures for OP. Finally, further studies are needed to understand the reasons for large treatment gaps in primary care, to identify potential solutions and appropriate steps to improve the treatment of $\mathrm{OP}$ and lower the occurrence of fracture in elderly women.

Supplementary Information The online version contains supplementary material available at https://doi.org/10.1007/s11657-021-01048-8. 
Funding This study was sponsored by Amgen. Medical writing support was provided by Deepali Mittal and Anand Jacob, employees of Bridge Medical, funded by Amgen.

\section{Declarations}

Ethics The study has been approved by the appropriate institutional and/or national research ethics committee; and has been performed in accordance with the ethical standards as laid down in the 1964 Declaration of Helsinki and its later amendments, or comparable ethical standards. Informed consent was obtained from all individual participants included in the study.

Conflicts of interest Eugene McCloskey: grants/research support from ActiveSignal, Amgen, AR UK, AstraZeneca, Consilient Healthcare, Fresenius Kabi GSK, Hologic, I3 Innovus, Internis, IOF, Lilly, Medtronic, Merck, MRC, Novartis, Pfizer, Roche, Sanofi-Aventis, Servier, Synexus, Tethys, UCB, Unilever, and Warner Chilcott. Consultant for ActiveSignal, Amgen, Consilient Healthcare, Fresenius Kabi, GSK, Synexus, and UCB. Speaking fees from Agnovos, Amgen, AstraZeneca, Consilient Healthcare, GSK, Hologic, Internis, Lilly, Pfizer, Roche, Servier, and UCB. Bernard Cortet has received fees for occasional interventions as an expert or speaker from Alexion, Amgen, Expanscience, Ferring, Lilly, Medtronic, MSD, Mylan, Novartis, Roche Diagnostics, and UCB. Edward Czerwinski has received a travelling grant from Amgen. Kerry Palmer, Robert Stad, James O'Kelly: Amgen employment and stock ownership. Socrates Papapoulos: Consulting/ speaking fees: Amgen, Myovant Sciences, Qualix DoT, Radius Health, UCB. Peyman Hadji: grants/research, consultancy, and lecture fees from Amgen, AstraZeneca, Dr. Kade/Besins, Exeltis, Gedeon Richter, Hexal, Hologic, Lilly, Mylan, Novartis, Pfizer, UCB. Jeetandera Rathi, Stephane Heijmans, Mark Blagden, Juraj Payer: No disclosures.

Open Access This article is licensed under a Creative Commons Attribution 4.0 International License, which permits use, sharing, adaptation, distribution and reproduction in any medium or format, as long as you give appropriate credit to the original author(s) and the source, provide a link to the Creative Commons licence, and indicate if changes were made. The images or other third party material in this article are included in the article's Creative Commons licence, unless indicated otherwise in a credit line to the material. If material is not included in the article's Creative Commons licence and your intended use is not permitted by statutory regulation or exceeds the permitted use, you will need to obtain permission directly from the copyright holder. To view a copy of this licence, visit http://creativecommons.org/licenses/by/4.0/.

\section{References}

1. Compston JE, McClung MR, Leslie WD (2019) Osteoporosis (seminar). Lancet 393:364-376

2. Tella H, Gallagher C (2014) Prevention and treatment of postmenopausal osteoporosis. J Steroid Biochem Mol Biol 142:155-170. https://doi.org/10.1016/j.jsbmb.2013.09.008

3. Borgström F, Karlsson L, Ortsäter G et al (2020) Fragility fractures in Europe: burden, management and opportunities. Arch Osteoporos 15:59. https://doi.org/10.1007/s11657-020-0706-y

4. Blain H, Masud T, Dargent-Molina P et al (2016) A comprehensive fracture prevention strategy in older adults: the European Union Geriatric Medicine Society (EUGMS) statement. J Nutr Health Aging 20(6):647-652. https://doi.org/10.1007/ s12603-016-0741-y
5. Kanis JA, Harvey NC, Cooper C et al (2016) A systematic review of intervention thresholds based on FRAX: a report prepared for the National Osteoporosis Guideline Group and the International Osteoporosis Foundation. Arch Osteoporos 11(1):25. https://doi. org/10.1007/s11657-016-0278-z

6. Rizzoli R (2018) Postmenopausal Osteoporosis: assessment and management. Best Pract Res Clin Endocrinol Metab 32(5):739757. https://doi.org/10.1016/j.beem.2018.09.005

7. Kanis JA, Cooper C, Rizzoli R et al (2019) European guidance for the diagnosis and management of osteoporosis in postmenopausal women. Osteoporos Int 30(1):3-44. https://doi.org/10.1007/ s00198-018-4704-5

8. Chotiyarnwong P, Harvey NC, Johansson H et al (2019) Temporal changes in access to FRAX ${ }^{\circledR}$ in Thailand between 2010 and 2018. Arch Osteoporos 14(1):66

9. Kanis JA, Svedbom A, Harvey N, McCloskey EV (2014) The osteoporosis treatment gap. J Bone Miner Res 29(9):1926-1928. https://doi.org/10.1002/jbmr.2301

10. Svedbom A, Hernlund E, Ivergård M et al (2013) Osteoporosis in the European Union: a compendium of country-specific reports. Arch Osteoporos 8(1-2):137. https://doi.org/10.1007/ s11657-013-0137-0

11. Svedbom A, Ivergård M, Hernlund E et al (2014) Epidemiology and economic burden of osteoporosis in Switzerland. Arch Osteoporos 9:187. https://doi.org/10.1007/s11657-014-0187-y

12. Cortet B, Chauvin P, Feron J-M et al (2020) Fragility fractures in France: epidemiology, characteristics and quality of life (the EPIFRACT study). Arch Osteoporos 15(1):46. https://doi.org/10. 1007/s11657-019-0674-2

13. McCloskey E, Rathi J, Heijmans S et al (2021) The osteoporosis treatment gap in patients at risk of fracture in European primary care: a multi-country cross-sectional observational study. Osteoporos Int 32(2):251-259. https://doi.org/10.1007/ s00198-020-05557-z

14. Compston J, Cooper A, Cooper C et al (2017) UK clinical guideline for the prevention and treatment of osteoporosis. Arch Osteoporos 12(1):43. https://doi.org/10.1007/s11657-017-0324-5

15. Sattari M, Cauley JA, Garvan C et al (2017) Osteoporosis in the women's health initiative: another treatment gap? Am J Med 130(8):937-948. https://doi.org/10.1016/j.amjmed.2017.02.042

16. Balasubramanian A, Tosi LL, Lane JM, Dirschl DR, Ho PR, O'Malley CD (2014) Declining rates of osteoporosis management following fragility fractures in the U.S., 2000 through 2009. J Bone Joint Surg Am 96(7):e52. https://doi.org/10.2106/JBJS.L. 01781

17. Kung AW, Fan T, Xu L et al (2013) Factors influencing diagnosis and treatment of osteoporosis after a fragility fracture among postmenopausal women in Asian countries: a retrospective study. BMC Womens Health 14(13):7. https://doi.org/10.1186/ 1472-6874-13-7

18. Wang L, Yu W, Yin X et al (2021) Prevalence of osteoporosis and fracture in China: the China Osteoporosis Prevalence Study. JAMA Netw Open 4(8):e2121106. https://doi.org/10.1001/jaman etworkopen.2021.21106

19. Alami S, Hervouet L, Poiraudeau S et al (2016) Barriers to effective postmenopausal osteoporosis treatment: a qualitative study of patients' and practitioners' views. PLoS One 11(6):e0158365. https://doi.org/10.1371/journal.pone.0158365

20. Merle B, Haesebaert J, Bedouet A et al (2019) Osteoporosis prevention: where are the barriers to improvement in French general practitioners? A qualitative study. PLoS One 14(7):e0219681. https://doi.org/10.1371/journal.pone.0219681

21. Salminen H, Piispanen P, Toth-Pal E (2019) Primary care physicians' views on osteoporosis management: a qualitative study. Arch Osteoporos 14:48. https://doi.org/10.1007/ s11657-019-0599-9 
22. Kanis JA, Norton N, Harvey NC et al (2021) SCOPE 2021: a new scorecard for osteoporosis in Europe. Osteoporos Int 16:82. https://doi.org/10.1007/s11657-020-00871-9

23. Morley J, Moayyeri A, Ali L et al (2020) Persistence and compliance with osteoporosis therapies among postmenopausal women in the UK Clinical Practice Research Datalink. Osteoporos Int 31(3):533-545. https://doi.org/10.1007/s00198-019-05228-8 (Epub 2019 Nov 22)

24. Hadji P, Kyvernitakis I, Kann PH et al (2016) GRAND-4: the German retrospective analysis of long-term persistence in women with osteoporosis treated with bisphosphonates or denosumab. Osteoporos Int 27:2967-2978

25. Raherison C, Girodet P-O (2009) Epidemiology of COPD. Eur Respir Rev 18:213-221

26. Dennison EM, Compston JE, Flahive J et al (2012) Effect of comorbidities on fracture risk: findings from the Global Longitudinal Study of Osteoporosis in Women (GLOW). Bone 50:1288-1293

27. Lacruz ME, Kluttig A, Hartwig S et al (2015) Prevalence and incidence of hypertension in the general adult population: results of the CARLA-cohort study. Medicine 94(22):e952. https://doi. org/10.1097/MD.0000000000000952
28. Mills KT, Bundy JD, Kelly TN et al (2016) Global disparities of hypertension prevalence and control: a systematic analysis of population-based studies from 90 countries. Circulation 134(6):441450. https://doi.org/10.1161/CIRCULATIONAHA.115.018912

29. Banks J, Batty GD, Nazroo J et al. (eds). The dynamics of ageing. Evidence from the English Longitudinal Study of Ageing (ELSA), 2002-16 (WAVE 8). The Institute for Fiscal Studies (2018). Available from: https://www.ifs.org.uk/uploads/ELSA_Wave_8_report. pdf.

30. Shepstone L, Lenaghan E, Cooper C et al (2018) for SCOOP Study Team. Screening in the community to reduce fractures in older women (SCOOP): a randomised controlled trial. Lancet 391:741-747

Publisher's Note Springer Nature remains neutral with regard to jurisdictional claims in published maps and institutional affiliations.

\section{Authors and Affiliations}

\section{Eugene McCloskey ${ }^{1}$. Jeetandera Rathi ${ }^{2}$. Stephane Heijmans ${ }^{3} \cdot$ Mark Blagden $^{4} \cdot$ Bernard Cortet $^{5}$. Edward Czerwinski ${ }^{6} \cdot$ Peyman Hadji $^{7,8}$. Juraj Payer ${ }^{9} \cdot$ Kerry Palmer $^{10} \cdot$ Robert Stad $^{11}$. James O'Kelly ${ }^{10}$. Socrates Papapoulos ${ }^{12}$}

1 Centre for Metabolic Bone Diseases, University of Sheffield, Sheffield, UK

2 Carrig Medical Centre, Cork, Ireland

3 ResearchLink, Linkebeek, Belgium

4 Ashgate Medical Practice, Chesterfield, UK

5 Department of Rheumatology and EA 4490, University-Hospital of Lille, Lille, France

6 Department of Bone and Joint Diseases, FHS, Jagiellonian University Medical College, Kopernika 32, 31-501 Krakow, Poland

7 Frankfurt Center of Bone Health, Frankfurt, Germany
Faculty of Medicine, 5th Department of Internal Medicine in University Hospital Bratislava, Comenius University, Bratislava, Slovakia

10 Amgen Ltd, Uxbridge, UK

11 Amgen Europe GmbH, Rotkreuz, Switzerland

12 Leiden University Medical Center, Leiden, Netherlands 